\title{
Construction of Chicken Drinking Water Sterilization Device Using Ultraviolet Light Based on ATMega8535 Microcontroller
}

\author{
Bisman Perangin-angin ${ }^{1^{*}}$ and Juliana br. Sembiring ${ }^{2}$ \\ ${ }^{1,2}$ Department of Physics, Faculty of Mathematics and Natural Science, Universitas Sumatera Utara, \\ Medan 20155, Indonesia
}

\begin{abstract}
This research aimed to design of a chicken drinking water sterilization device using ultraviolet light-based microcontroller ATMega8535. After constructing the device, the test that is carried out were running the system according to the procedure, observing the performance of the system that begins with setting the sterilization timer at the minimum position, and recording the results. After the power supply was activated, the potentiometer of timer set to a minimum. The pump was on for 1 minute, then the UV lamp was also active and the process continues to repeat. Potentiometer was set to increase by $50 \%$ timer in 5 minutes position, and raised again to $100 \%$ at 10 minute position. The control process of this system is carried out by an ATMega8535 microcontroller that regulates the process of draining water from the container to the pipe, the length of time it takes to activate the ultraviolet lamp and the length of time it takes to activate the pump. This device was designed to demolish germs and bacteria in the water. The test resulted in a $100 \%$ reduction in bacteria in ultraviolet-illuminated water.
\end{abstract}

Keyword: sterilization, drinking water chicken, UV rays, microcontroller, ATMega8535.

Received 5 February 2021 | Revised [19 February 2021] | Accepted [25 February 2021]

\section{Introduction}

Indonesia is a country that has a livestock sector as an important role holder for its economic growth. Director General of Animal Husbandry and Health (Director General of PKH) of the Ministry of Agriculture I, Ketut Diarmita said that based on data for the establishment of National Gross Domestic Product (GDP), the livestock sector contributed by $15.87 \%$ [1]. In view of this situation, the livestock sector in Indonesia must be given special attention in order to improve its quality.

Water is a very vital element in the development of livestock business [2]. If the management is good then the profit can be achieved, on the contrary if mis-managing management can have bad consequences [3]. Water required by humans must meet quantitatively and qualitatively.

\footnotetext{
*Corresponding author at: Jalan Biolteknologi no.1 Medan, 20155, Indonesia

E-mail address: bisman@usu.ac.id
} 
Quantitative aspect, the amount of water needed for drinking needs per person is on average as much as 2.5 liters/day, while the overall needs of a household for the people of Indonesia is estimated at 60 liters/day. Aspects of quality, drinking water and clean water must meet health requirements both physically, chemically, microbiologically and radioactive in accordance with government regulations through the Department of Health and the environment.

Groundwater is generally relatively clean in terms of microbiological, but the chemical content of groundwater depends on the lithosphere formation it passes through or there may be pollution from the surrounding environment [4]. One of the management that needs to be considered is drinking water of livestock. Water hygiene is difficult to maintain because chickens will contaminate the drinking place (with fecal contamination or husks), so it needs to be cleaned daily [5]. Employees also have to refill the water when consumed by chickens.

Local chicken farming businesses can be developed by applying advanced technology so as to increase farmers' productivity and income. Diseases in local chickens are generally caused by viral, bacterial, protozoan and parasitic infections. However, local chickens are generally more resistant to diseases, especially avian influenza (AI) or bird flu, than purebred chickens because they have a higher percentage of antiviral genes $(\mathrm{Mx}+)$ [6]. Breeding programs to form diseaseresistant local chicken strains, especially AI and tetelo or newcastle disease (ND), need to be realized and supported by infectious disease control programs. It not only consumes energy, but also wastes water. Drinking water is also at risk of frequent spillover by excessive chicken activity which can cause liters of moisture and increased ammonia levels. Humid conditions and high ammonia can certainly be a source of disease in the cage [7].

UV-mercury lamps are surrounded by quartz cooling tubes with a bow length of $25 \mathrm{~cm}$. To extend the life of UV-mercury lamps, UV-mercury lamps are cooled with water at a temperature of $12^{\circ} \mathrm{C}-16^{\circ} \mathrm{C}$ and watered with inert gas (nitrogen). Uv-mercury lamp power (P) is about 1000-3000 W. UV-mercury lamp made by Philips model T5 with $8 \mathrm{~W}$ power, T8 model with 30 $\mathrm{W}$ power, and T12 model with $40 \mathrm{~W}$ power to produce UV-A/B light marketed in Indonesia has a service life of about 3000 hours or 4.16 months [8]. Water must also be free from suspended particles aka not cloudy, from coarse mud, fine mud or colloids [9]. The physical condition of drinking water in addition, the physical quality of water can be affected due to the presence of excess chemical content in water e.g. water that is reddish-brown indicates high iron levels [10].

\section{Methods}

\subsection{Block Diagram}

A block diagram of the designed system is shown in Figure 1, describing the configuration of system inputs and outputs. The input is water to be sterilized, which is well water that still contains germs and bacteria. Well water is accommodated in a container and then circulated to ultraviolet light using ultraviolet lamps continuously and continuously [11]. Sterilization 
process with ultraviolet light at a predetermined period, then the water is in a sterile state or free from germs and bacteria, so it is ready to be flowed out into the channel leading to the livestock drinking water reservoir. Water that has undergone sterilization process is called output [12].

The process of draining the circulation of water from the water reservoir to the pipe where the water will be flowed, a water pump is needed [13]. The control process of this system is carried out by an Atmega 8535 microcontroller that regulates the process of draining water from the reservoir to the pipe, the length of time it takes to activate the ultraviolet lamp and the length of time it takes to activate the pump [14].

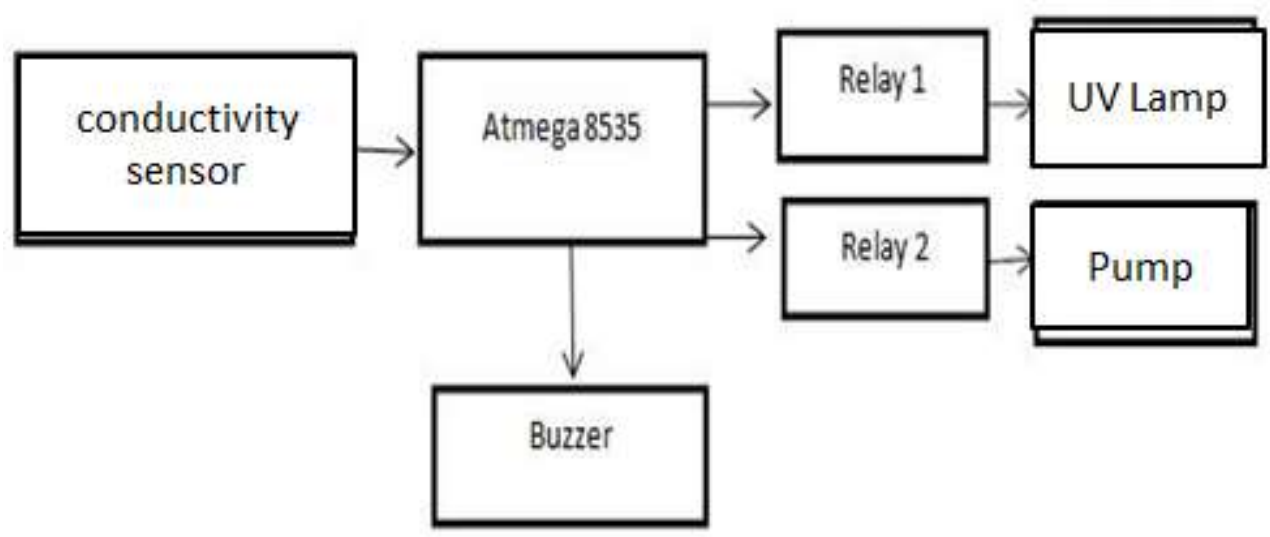

Figure 1. The block diagram of the device

\subsection{M1632 LCD Display Testing}

LCD testing uses a specially created program to display a message on the LCD by a microcontroller. The program is made in $\mathrm{C}$ language, and run on microcontrollers with the condition of connecting between microcontroller and LCD.

\subsection{Ultraviolet Lamp Testing}

Ultraviolet lamp used is ultraviolet fluorescent lamp that serves to illuminate water to be sterilized from germs or bacteria, so that germs or bacteria contained in water can be lost, so that water will be clean and worthy to be consumed by chickens [15]. The duration of the lamp for life can be adjusted by setting the position of the potentiometer. This ultraviolet lamp will live according to the needs of the user in the amount of water [16].

\subsection{Testing of Water Pumps and Water Sensors}

The water pump used is a plastic water dye pump so that it lasts in the water. In general, these pumps are used in aquarium systems for the water filtration process. The pump tested its performance which is the amount of water discharge that can be flowed unity time. For this test, water containers and water measuring devices are needed. In this experiment used a 5 liter gallon water container as a container. The pump is dipped in water in the container where the water supply is then turned on to fill the gallon container to the full. Note the length of time it 
takes for the charging process. In order to be more thorough results, several experiments were carried out and taken on average.

Water sensor is a tool used to signal alarm/automation panel that the water level has reached a certain level. The sensor will provide dry contact signal to the panel. Detection of water level by reading the voltage value produced by each voltage division series was composed by four outputs [17-19]. To test the water sensor simply use a voltmeter and voltage source. The output logic will determine whether the sensor is water-dipped or not.

\subsection{ATMega8535 Microcontroller Testing}

ATMega 8535 microcontroller testing was conducted to determine whether the controller circuit had worked according to the program or not, by comparing the data between the program data created and the measurement results. Each output port is measured by voltmeter then compared to the programmable data. If there is a logic difference then there is an error. Algorithms of programs written in $\mathrm{C}$ language are as follows:

DDRA $=0 x F F$

PORTA = 0x66;

$\mathrm{DDRB}=0 \mathrm{xFF} ;$

PORTB $=0 \times 41 ;$

$\mathrm{DDRC}=0 \mathrm{xFF}$

PORTC $=0 \times A 5$;

$\mathrm{DDRD}=0 \mathrm{xFF}$

PORTD $=0 x F 1$;

\subsection{Overall System Testing}

Testing is done after all components are integrated into one including the entire program that has been created. Testing is carried out by running the system according to the procedure and observing the performance of the system that begins with setting the sterilization timer at the minimum position and recording the results [20]. After the observation, the work process was running on the system.

Power supply activated, potentiometer timer set to a minimum. The pump is on for 1 minute, then the UV lamp is also active and the process continues to repeat. Potensiometer is set to increase by $50 \%$ timer in 5 minutes position, then raised again to $100 \%$ at 10 minute position. Testing is also done by dumping water through the output channel that is on each nepel or spot where chickens drink water. Over time the water will decrease and eventually there will be little left in the container or water tank. When the water reaches a volume below $20 \%$ the buzzer starts to sound and continues to sound until the water is replenished by the owner. 


\subsection{Water Testing}

Water testing is carried out in the Biology Laboratory of FMIPA USU with the Total Plate Count (TPC) method on well water before being given ultraviolet radiation and after being given ultraviolet radiation.

\section{Result and Discussion}

\subsection{M1632 LCD Display Test Results}

Here is a program made for lcd display testing LCD M1632.

lcd_gotoxy $(0,0)$;

lcd_putsf(“ALAT STERILISASI”);

lcd_gotoxy $(0,1)$;

lcd_putsf(“AIR MINUM TERNAK”); delay_ms(2000);

lcd_clear();

lcd_gotoxy $(0,0)$;

lcd_putsf(“DGN ULTRA VIOLET"); 1cd_gotoxy $(0,1)$;

lcd_putsf(“"”);

delay_ms(2000);

Once executed on the series, when enabled the display displays a message "ALAT STERILISASI AIR MINUM TERNAK DGN ULTRAVIOLET",

\subsection{Water Pump and Water Sensor Test Results}

Table 1. Water Pump Test Result

\begin{tabular}{ccc}
\hline Experiment & time (minute) & Total volume \\
\hline 1 & 1.58 & $5 \mathrm{~L}$ \\
2 & 1.67 & $5 \mathrm{~L}$ \\
3 & 1.54 & $5 \mathrm{~L}$ \\
\hline
\end{tabular}

The average measurement results above are: Average $=(1.58+1.67+1.54) / 3=1.59$ minutes $/ \mathrm{L}$. or $:$ Debit $=5 \mathrm{~L} / 1.59$ minutes $=3.14 \mathrm{~L} /$ minute $=189.2 \mathrm{~L} /$ Hour. Test results showed the discharge that can be flowed by the pump for 1 hour is 189.2 liters of water.

Table 2. Water Sensor Test Results (Conductivity)

\begin{tabular}{ccc}
\hline Sensor condition & Output Voltage $(\mathrm{V})$ & Logic \\
\hline Not Dyed & 4.97 & 1 \\
Dyed & 0.72 & 0 \\
\hline
\end{tabular}

The sensor is attached between the microcontroller input on one of the input and ground ports. The input port is programmed with a 1 or pull up logic. Thus when not dipped in water, there is no conduction between the ground and the microcontroller input, therefore the logic will remain high with a voltage approaching $5 \mathrm{~V}$. When the sensor is dipped in water, the conductivity of 
water will make the voltage flow to the ground and make the voltage drop to close to 0 so that the logic is read by the microcontroller to Low.

\subsection{ATMega8535 Microcontroller Testing Results}

Table 3. ATMega Microcontroller Testing Results 8535

\begin{tabular}{cccc}
\hline Port A & Port B & Port C & Port D \\
\hline 0.02 & 4.97 & 4.91 & 0.01 \\
4.99 & 0.00 & 0.01 & 0.00 \\
4.98 & 0.00 & 4.99 & 0.00 \\
0.01 & 0.00 & 0.01 & 0.00 \\
0.01 & 0.00 & 0.01 & 5.01 \\
5.00 & 0.00 & 5.02 & 4.99 \\
5.00 & 5.01 & 0.00 & 5.01 \\
0.01 & 0.00 & 4.98 & 4.99 \\
\hline
\end{tabular}

Thus the output log data of each port are:

PORTA : 01100110

PORTB : 10000010

PORTC : 10100101

PORTD : 11110001

\subsection{Overall System Test Results}

Table 4. Overall System Test Results

\begin{tabular}{ccc}
\hline Time & Pump Condition & Ultraviolet conditions \\
\hline 60 seconds & Active & Active \\
120 seconds & Non Active & Non Active \\
\hline
\end{tabular}

Table 4 shows that the duration of the pump is active for 1 minute and is off for 1 minute. This means that the pump will turn on and circulate every 1 minute. While in UV lamps whose timer is set at the minimum position of life and death duration is 1 minute or 60 seconds.

\subsection{Water Test Results}

Based on the results of the Total Plate Count (TPC) test on well water samples, data obtained as in Table 5 .

Table 5. Water Test Result

\begin{tabular}{ccc}
\hline Number & Sample Code & $\begin{array}{c}\text { Number of Bacterial } \\
\text { Colonies (CFU/ml) }\end{array}$ \\
\hline 1. & Before being treated & 168 \\
2. & After being treated & 0 \\
\hline
\end{tabular}

Table 5 shows a $100 \%$ reduction in bacteria in ultraviolet-illuminated water. 


\section{Conclusion}

This cattle drinking water sterilizer works well. Water circulation system controlled by an AVR microcontroller namely ATMega8353 with water pump performs the circulation process periodically with time that can be regulated by the user through the potentiometer on the input. The minimum time is 1 minute and a maximum of 10 minutes of ultraviolet irradiation. This livestock drinking water sterilizer is able to kill germs or bacteria in water; this is evidenced by the reduction of bacteria by $100 \%$ in water that has been illuminated by ultraviolet.

\section{REFERENCES}

[1] J. H. Auer, \& H. C. Sibley, U.S. Patent No. CA1053791A, 01 May 1979.

[2] H. C. Sibley, U.S. Patent No. US4181849A, 30 January 1978.

[3] R. E. Morgan, U.S. Patent No. US4631627A, 09 May 1985.

[4] T. Rahayu, "Karakteristik Air Sumur Dangkal di Wilayah Kartasura dan Upaya Penjernihannya," Jurnal Penelitian Sains dan Teknologi, vol. 5, no. 2, pp. 104-124, 2004.

[5] O. H. Cahyonugroho, "Pengaruh Intensitas Sinar Ultraviolet dan Pengadukan Terhadap Reduksi Jumlah Bakteri E. Coli," Jurnal Ilmiah Teknik Lingkungan, vol. 2, no. 1, pp. 1823, 2011.

[6] A. G. Nataamijaya, "Pengembangan Potensi Ayam Lokal untuk Menunjang Peningkatan Kesejahteraan Petani,"Jurnal Litbang Pertanian, vol. 29, no. 4, pp. 131-138, 2010.

[7] D. Susanto, T. U. Kalsum and Y. Suzantri H, "Alat Penyaringan Air Kotor Menjadi Air Bersih Menggunakan Mikrokontroler ATMega 32," Jurnal Media Infotama, vol. 10, no. 2, pp. 142-150, 2014.

[8] C. Widiyati and H. Poernomo, "Kajian Teknologi Pra-Vulkanisasi Lateks Karet Alam Secara Iradiasi UV-A Dari Lampu Light Emitting Diode," Prosiding Pertemuan dan Presentasi Ilmiah Teknologi Akselerator dan Aplikasinya, vol. 14, pp. 63-73, 2012.

[9] A. Bejo, C \& AVR Rahasia Kemudahan Bahasa C dalam Mikrokontroler Atmega 8535, Yogyakarta: Graha Ilmu, 2008.

[10] Z. Hu, R. G. Askin and G. Hu, "Hub Relay Network Design for Daily Driver Routes," International Journal of Production Research, vol. 57, no. 19, pp. 6130-6145, 2019.

[11] A. MacLean, U.S. Patent No. US4133020A, 04 October 1976.

[12] N. Istichoroh and A. Prihanto, "Simulasi Karakteristik Dioda dengan Menggunakan Bahasa Pemrograman Delphi 7.0," Jurnal Fisika, vol. 2, no. 1, pp. 01-06, 2013.

[13] T. A. Gambill and R. B. Fell, U.S. Patent No. US5250893A, 05 October 1993.

[14] S. L. Tobing, "Rancang Bangun Pengaman Pintu Menggunakan Sidik Jari (Fingerprint) dan Smartphone Android Berbasis Mikrokontroler ATMega8," Jurnal Teknik Elektro Universitas Tanjungpura, vol. 1, no. 1, pp. 1-7, 2014.

[15] M. Tooley, Rangkaian Elektronik Prinsip dan Aplikasi, edisi kedua. Jakarta: Erlangga, 2003.

[16] E. Nasrullah, "Prototipe Pengaman Pintu Menggunakan Kunci Digital Berbasis Pengendali Mikro ATMega8535," ELECTRICIAN Jurnal Rekayasa dan Teknologi ELektro, vol. 3, no. 2, pp. 81-89, 2009.

[17] A. Fares, and V. Polyakov, "Advances in crop water management using capacitive water sensors", Advances in agronomy, vol. 90, pp.43-77, 2006.

[18] N. A. Cloete, R. Malekian, and L. Nair, "Design of smart sensors for real-time water quality monitoring", IEEE access, vol. 4, pp.3975-3990, 2016.

[19] K. Murphy, B. Heery, T. Sullivan, D. Zhang, L. Paludetti, K. T. Lau, D. Diamond, E. Costa, and F. Regan, "A low-cost autonomous optical sensor for water quality monitoring", 
Talanta, vol. 132, pp.520-527, 2015.

[20] A. S. Samosir, N. I. Tohir and A. Haris, "Rancang Bangun Catu Daya Digital Menggunakan Buck Converter Berbasis Mikrokontroler Arduino," ELECTRICIAN Jurnal Rekayasa dan Teknologi ELektro, vol. 11, no. 1, pp. 44-52, 2017. 